\title{
Transient expression of the cancer/testis cancer antigen NY-ESO-1 in Nicotiana benthamiana using a PVX-based viral vector
}

\author{
Cristiano Lacorte ${ }^{1 *}$, Jéssica Carrijo ${ }^{2}$, André Murad $^{1}$, Elíbio Rech ${ }^{1}$ \\ From 5th Congress of the Brazilian Biotechnology Society (SBBIOTEC) \\ Florianópolis, Brazil. 10-14 November 2013
}

\section{Background}

Cancer/testis antigens is a group of proteins which expression is usually restricted to the human germ line but is also present at high levels in several types of cancer cells [1]. The antigen NY-ESO- 1 is one of these antigens showing high immunogenicity and, therefore, holding great potential for a cancer vaccine [2]. Its heterologous expression is being tested in different expression systems, although the success has been limited [2,3]. In this report we used a transient expression system based on a PVX viral vector to evaluate the expression of NY-ESO-1 in leaves of Nicotiana benthamina.

\section{Methods}

The NY-ESO-1 antigen coding sequence was synthetized based on a plant codon optimized sequence. The correspondent fragment was cloned in a pDonr207 derived vector containing a hexa-histidine tag (6His) and signal peptides for the endoplasmic reticulum (ER), apoplast or chloroplast. These vectors were recombined to a Gateway $^{\circledR}$-compatible PVX-based vector using the LR clonase, and transferred to Agrobacerium tumefaciens strain GV3101 containing the pSoup vector [4]. Nicotiana benthamina plants were inoculated with Agrobacterium suspensions through vacuum infiltration. After 4-5 days, leaves were collected and macerated in phosphate saline buffer (PBS) at a 1:2 (w:v) ratio and analyzed by Western blot.

To further characterize and quantify the expression levels of recombinant NY-ESO-1, leaf extracts were analyzed by nanoUPLC-MS ${ }^{\mathrm{E}}$ [5]. To this end, leaves were grinded and proteins were extracted using $50 \mathrm{mM}$

${ }^{1}$ Embrapa Recursos Genéticos e Biotecnologia, Estação Parque Biológica, 70770-910, Brasília, DF, Brazil

Full list of author information is available at the end of the article
Tris- $\mathrm{HCl} \mathrm{pH} 8.0$ in 1:20 (w:v) ratio. Proteins were precipitated with acetone, resuspended in water and quantified using the Qubit ${ }^{\circledR}$ fluorimetric assay.

\section{Results and conclusions}

The expression of cancer/testis NY-ESO-1 antigen was detected in N. benthamiana leaves using a PVX-based transient assay. Different constructs were tested containing signal peptides for ER, apoplast and chloroplast. No signal was detected when the NY-ESO-1 antigen was targeted to chloroplast or to the apoplast and detection was only possible when the protein was targeted to the ER, indicating that NY-ESO-1 accumulation in leaf tissue is influenced by the subcellular localization. NanoUPLC-MS ${ }^{\mathrm{E}}$ analysis confirmed the presence of heterologous NY-ESO-1 in a level of approximately $0.1 \%$ of the total soluble protein extract.

This assay allows protein to be detected after only 4-5 days after inoculation thereby eliminating the need of long and cumbersome tissue culture and selection schemes necessary for transgenic plants production. It also represents a handy and fast method to evaluate different gene constructs.

\section{Acknowledgements \\ FAP-DF, CAPES, CNPq, Embrapa.}

\section{Authors' details}

'Embrapa Recursos Genéticos e Biotecnologia, Estação Parque Biológica, 70770-910, Brasília, DF, Brazil. ²Centro de Análises Proteômicas e Bioquímicas, Universidade Católica de Brasília, Brasília, DF, Brazil.

\section{Published: 1 October 2014}

\section{References}

1. Caballero OL, Chen YT: Cancer/testis (CT) antigens: potential targets for immunotherapy. Cancer science 2009, 100(11):2014-2021. 
2. Simpson AJ, Caballero OL, Jungbluth A, Chen YT, Old LJ: Cancer/testis antigens, gametogenesis and cancer. Nature reviews 2005, 5(8):615-625

3. Lowe AJ, Bardliving $C L$, Huang $C J$, Teixeira LM, Damasceno LM, Anderson KA, Ritter G, Old $L$, Batt CA: Expression and purification of cGMP grade NY-ESO-1 for clinical trials. Biotechnology progress 2011, 27(2):435-441.

4. Lacorte C, Ribeiro SG, Lohuis D, Goldbach R, Prins M: Potatovirus $\times$ and Tobacco mosaic virus-based vectors compatible with the Gateway cloning system. Journal of virological methods 2010, 164(1-2):7-13.

5. Murad AM, Souza GH, Garcia JS, Rech EL: Detection and expression analysis of recombinant proteins in plant-derived complex mixtures using nanoUPLC-MS(E). Journal of separation science 2011, 34:2618-2630.

doi:10.1186/1753-6561-8-S4-P76

Cite this article as: Lacorte et al:: Transient expression of the cancer/ testis cancer antigen NY-ESO-1 in Nicotiana benthamiana using a PVXbased viral vector. BMC Proceedings 2014 8(Suppl 4):P76.

\section{Submit your next manuscript to BioMed Central} and take full advantage of:

- Convenient online submission

- Thorough peer review

- No space constraints or color figure charges

- Immediate publication on acceptance

- Inclusion in PubMed, CAS, Scopus and Google Scholar

- Research which is freely available for redistribution

Submit your manuscript at www.biomedcentral.com/submit 